\title{
The origin of newborn hepatocytes in associating liver partition and portal vein ligation for staged hepatectomy (ALPPS)-derived regeneration
}

\author{
Yifan Tong ${ }^{1,2}$, Yongfen $\mathrm{Zhu}^{3}$, Xiujun Cai ${ }^{1,2}$ \\ ${ }^{1}$ Department of General Surgery, ${ }^{2}$ Zhejiang Provincial Key Laboratory of Laparoscopic Technology, ${ }^{3}$ Department of Hepatology and Infection, Sir \\ Run Run Shaw Hospital, School of Medicine, Zhejiang University, Hangzhou, China \\ Correspondence to: Xiujun Cai, MD, FACS, FRCS. Department of General Surgery, Sir Run Run Shaw Hospital, School of Medicine, Zhejiang \\ University, Hangzhou, China. Email: srrsh_cxj@zju.edu.cn.
}

Submitted Dec 09, 2019. Accepted for publication Mar 03, 2020.

doi: $10.21037 /$ hbsn.2020.03.13

View this article at: http://dx.doi.org/10.21037/hbsn.2020.03.13

Associating liver partition and portal vein ligation for staged hepatectomy (ALPPS) has attracted interest in the field of hepatobiliary surgery worldwide (1). Given the significant improvement in morbidity and mortality, the ALPPS became safer in experienced centres, while research on the mechanism of ALPPS lags far behind clinical studies. Despite basic studies showing that activated hepatic stellates via Indian hedgehog/Gli1 pathway, mitochondria metabolism and inflammation were involved in ALPPS-derived regeneration, the cellular source of rapid self-duplication of hepatocytes during ALPPS stage I has not been well-documented $(2,3)$. Therefore, the aim of this study was to explore the origin of newborn hepatocytes during ALPPS procedure.

In this study, Rosa26 $6^{\text {loxP-mTomato-stop-loxP-mGFP }}(\mathrm{mTmG})$ male mice (from Hui Lijian Lab, Institute of Biochemistry and Cell Biology, Shanghai), aged 8 weeks were housed in a restricted access room with a controlled temperature ( 23 centigrade) and a 12-hour light-dark cycle and had free access to food and water before and after treatment. All studies were according to animal research reporting in vivo experiments guidelines and approved by the animal ethics committee of Zhejiang University, China. In this lineage tracing mice, the cells including hepatocytes, progenitors, biliary epithelial cells (BECs), and others nonparenchymal cells are $\mathrm{mTom}^{+}$. When the organ-specific Cre virus is given, the targeted cells and their daughter cells could turn from $\mathrm{mTom}^{+}$to $\mathrm{mGFP}^{+}$, while other cells and their daughter cells remain $\mathrm{mTom}^{+}$. Therefore, we used the hepatocytespecific AAV8-thyroxine-binding globulin (TBG)-Cre virus (AV1159, Vigenebio, China) to label the hepatocytes through tail vein injection. The labelled hepatocytes and their daughter cells will turn from mTom ${ }^{+}$to $\mathrm{mGFP}^{+}$, while unlabelled hepatocytes and other cells including hepatic progenitor cells (HPCs), biliary epithelium cells BECs, etc., remain $\mathrm{mTom}^{+}$. Under general anaesthesia using an automatic delivery system, a surgical microscope was used during the entire surgical procedure. After a cholecystectomy was conducted, ligation of the portal vein branches supplying the left lateral, left middle, right and caudate lobes with 9-0 silk was performed microscopically. The artery and biliary duct branches were maintained. Eventually, the parenchyma transection was performed through the middle lobe along the demarcation line. As the future liver remnant (FLR) after ALPPS stage I (referred to as ALPPS) at $7^{\text {th }}$ and $14^{\text {th }}$ days were comparable (data not shown), we detected the regeneration of FLR at $14^{\text {th }}$ day when the proliferation of FLR was almost finished. Liver regeneration was assessed by right middle lobe weight/body weight $(\mathrm{BW}) \times 100 \%$ and the ratio of $\mathrm{mTom}^{+}$to $\mathrm{mGFP}^{+}$hepatocytes (4). Data are expressed as the mean with the standard deviation and compared with Student's $t$-test. Significance was defined when the two-tailed $\mathrm{P}$ value was less than 0.05 .

By different concentrations of AAV8-TBG-Cre virus to quantitative labelling efficiency, we verified that low-dose virus $\left(5^{*} \mathrm{E} 11 \mathrm{v.g}\right)$ labelled $89.1 \%$ hepatocytes, high-dose $\left(10^{*} \mathrm{E} 11 \mathrm{v} . \mathrm{g}\right)$ virus labelled over $99.9 \%$ hepatocytes, and no $\mathrm{mGFP}^{+}$hepatocyte was labelled in control group (AAV8TBG-Blank) (Figure 1A). Two weeks later, virus-challenged mice underwent ALPPS or sham, respectively, then were sacrificed after another two weeks (Figure 1B). The FLR 


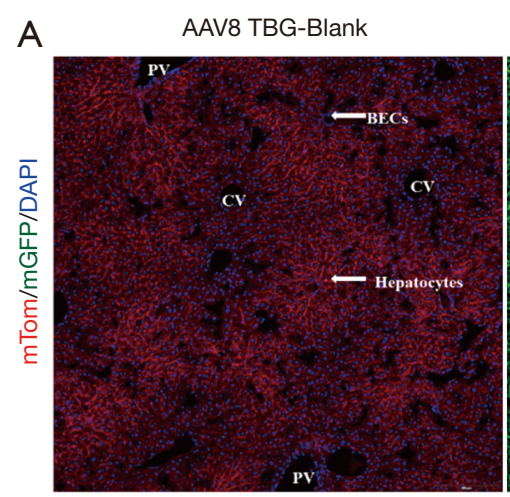

B
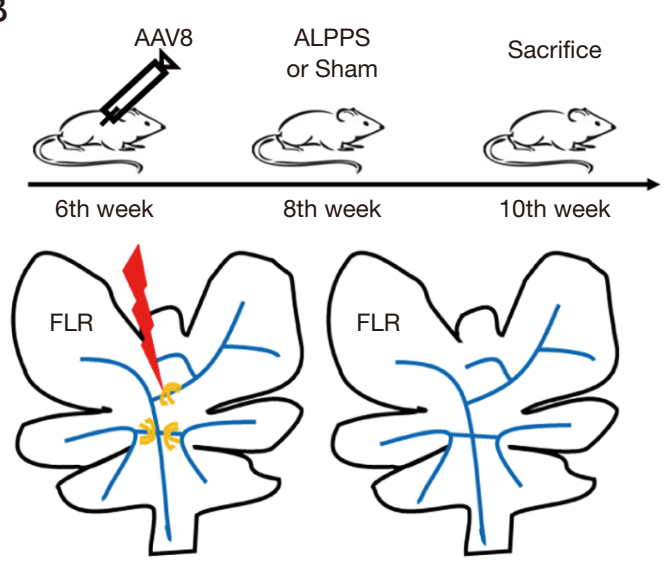

ALPPS
AAV8 TBG-Cre $\left(5^{\star} \mathrm{E} 11\right.$ v.g)

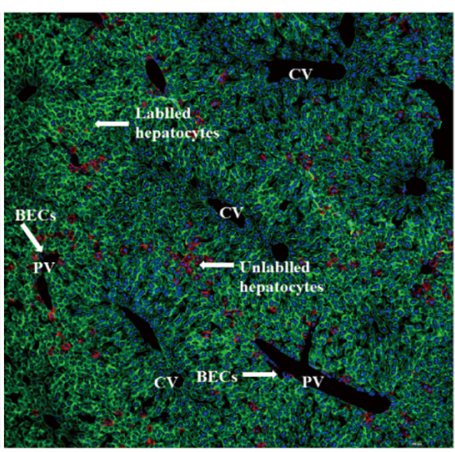

AAV8 TBG-Cre (10*E11 v.g)

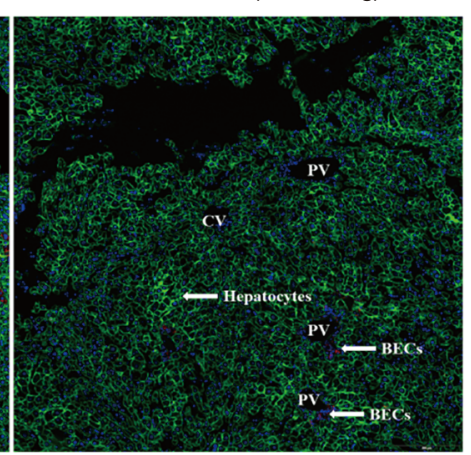

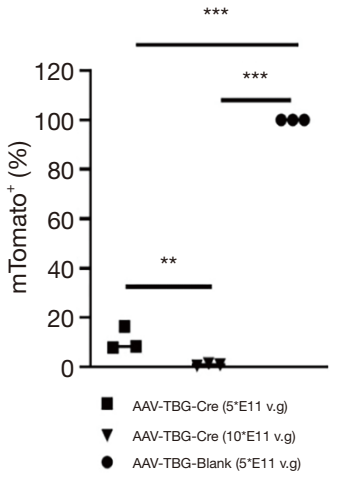

D $\quad$ AAV8 TBG-Cre $\left(5^{\star} \mathrm{E} 11 \mathrm{v} . \mathrm{g}\right)$

AAV8 TBG-Cre (10E11 v.g)
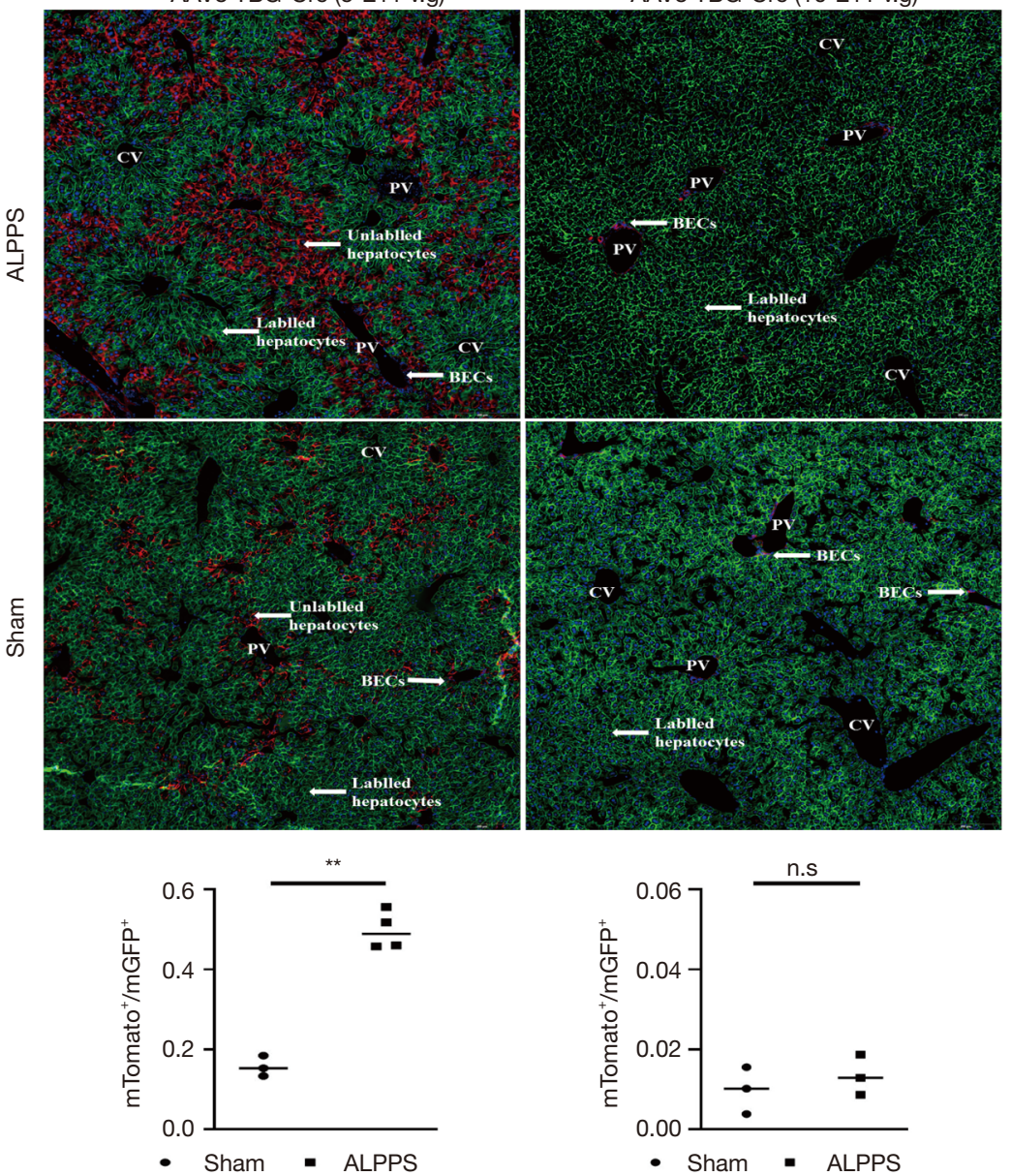

Figure 1 The origin of newborn hepatocytes in ALPPS-derived regeneration. (A) Labelling efficiency quantitative analysis ( $\times 200)$; (B) time schedule and schematic map of operations, yellow circles represent ligation of portal veins, red flash represents transection of parenchyma; (C) proliferation of FLR; (D) ratio of $\mathrm{mTom}^{+}$hepatocyte $(\times 200) .{ }^{* *}, \mathrm{P}<0.01$; ${ }^{* * *}, \mathrm{P}<0.001$. ALPPS, associating liver partition and portal vein ligation for staged hepatectomy; FLR, future liver remnant; BW, body weight, BECs, biliary epithelium cells; CV, central vein; PV, portal vein. 
in the ALPPS group was $0.0235 \pm 0.0002$, significantly higher than $0.0098 \pm 0.0002$ in the sham group after lowdose virus treatment $(\mathrm{P}<0.001)$. In terms of high-dose virus treatment, the FLR in the ALPPS and sham groups were $0.0233 \pm 0.0002$ and $0.0095 \pm 0.0005$, respectively $(\mathrm{P}<0.001)$ (Figure 1C). In low-dose virus challenged groups, the ratio of $\mathrm{mTom}^{+}$to $\mathrm{mGFP}^{+}$hepatocytes in the ALPPS group increased to $0.498 \pm 0.048$, approximately 3.2 folds higher than $0.157 \pm 0.026$ in the sham group $(\mathrm{P}<0.001)$. However, further investigation in high-dose virus challenged groups showed no mTom ${ }^{+}$hepatocyte was presented in the ALPPS or sham group (Figure 1D).

HPCs, anatomically located in portal triad, are hepatic stem-like cells, displaying self-renewal capability and differentiating into mature hepatocytes as well as BECs during injury (5). Generally, HPCs are partially responsible for regeneration only if the self-renewal of mature hepatocytes is severe damaged (6). Accumulating evidences supported that ALPPS-induced newborn hepatocytes are immature (7). Correspondingly, the YAP pathway, highly expressed in the progenitor cell compartments, is distinctly activated after ALPPS (8). Therefore, HPCs are presumably triggered to restore normal liver structure and function as the ALPPS accelerates proliferation of FLR by redistribution of portal blood flow. Given the lineage tracing model by labelling hepatocyte and its offspring provided a chance to visualize the newborn hepatocyte origin during ALPPSderived regeneration, we illustrated that the number of hepatocytes in the FLR increased rapidly after ALPPS stimulation with low-dose virus treatment. However, the plenty of $\mathrm{mTom}^{+}$hepatocytes derived from unlabelled mature hepatocytes or HPCs remained controversial. After highdose virus treatment, no $\mathrm{mTom}^{+}$hepatocyte was manifested at 14th day after ALPPS, which suggested that replenish of FLR was mediated by $\mathrm{mGFP}^{+}$hepatocytes and their daughter cells. Above, we revealed that no HPCs were induced during ALPPS-derived regeneration and all newborn hepatocytes were originated from mature hepatocytes.

\section{Acknowledgments}

Many thanks to professor Hui Lijian (State Key Laboratory of Cell Biology, Institute of Biochemistry and Cell Biology, Shanghai Chinese Academy of Sciences) for providing the mTmG mice.

Funding: This study was supported by the Natural Science Foundation of Zhejiang Province (grant No LY15H030009).

\section{Footnote}

Provenance and Peer Review: This article is a free submission to the Hepatobiliary Surgery and Nutrition. The article has undergone external peer review.

Conflicts of Interest: All authors have completed the ICMJE uniform disclosure form (available at http://dx.doi. org/10.21037/hbsn.2020.03.13). The authors have no conflicts of interest to declare.

Ethical Statement: The authors are accountable for all aspects of the work in ensuring that questions related to the accuracy or integrity of any part of the work are appropriately investigated and resolved.

Open Access Statement: This is an Open Access article distributed in accordance with the Creative Commons Attribution-NonCommercial-NoDerivs 4.0 International License (CC BY-NC-ND 4.0), which permits the noncommercial replication and distribution of the article with the strict proviso that no changes or edits are made and the original work is properly cited (including links to both the formal publication through the relevant DOI and the license). See: https://creativecommons.org/licenses/by-nc-nd/4.0/.

\section{References}

1. Olthof PB, Schnitzbauer AA, Schadde E. The HPB controversy of the decade: 2007-2017 - Ten years of ALPPS. Eur J Surg Oncol 2018;44:1624-7.

2. Langiewicz M, Schlegel A, Saponara E, et al. Hedgehog pathway mediates early acceleration of liver regeneration induced by a novel two-staged hepatectomy in mice. J Hepatol 2017;66:560-70.

3. Budai A, Horváth G, Tretter L, et al. Mitochondrial function after associating liver partition and portal vein ligation for staged hepatectomy in an experimental model. Br J Surg 2019;106:120-31.

4. Deng X, Zhang X, Li W, et al. Chronic Liver Injury Induces Conversion of Biliary Epithelial Cells into Hepatocytes. Cell Stem Cell 2018;23:114-122.e3.

5. Tarlow BD, Pelz C, Naugler WE, et al. Bipotential adult liver progenitors are derived from chronically injured mature hepatocytes. Cell Stem Cell 2014;15:605-18.

6. Font-Burgada J, Shalapour S, Ramaswamy S, et al. Hybrid Periportal Hepatocytes Regenerate the Injured Liver without Giving Rise to Cancer. Cell 2015;162:766-79. 
7. Tong YF, Meng N, Chen MQ, et al. Maturity of associating liver partition and portal vein ligation for staged hepatectomy-derived liver regeneration in a rat model. World J Gastroenterol 2018;24:1107-19.

Cite this article as: Tong Y, Zhu Y, Cai X. The origin of newborn hepatocytes in associating liver partition and portal vein ligation for staged hepatectomy (ALPPS)-derived regeneration. HepatoBiliary Surg Nutr 2020;9(5):687-690. doi: $10.21037 / \mathrm{hbsn} .2020 .03 .13$
8. Shi JH, Hammarström C, Grzyb K, et al. Experimental evaluation of liver regeneration patterns and liver function following ALPPS. BJS Open 2017;1:84-96. 